\title{
Antiviral Defense Involves AGO4 in an Arabidopsis-Potexvirus Interaction
}

\author{
Chantal Brosseau, ${ }^{1}$ Mohamed El Oirdi, ${ }^{1,2}$ Ayooluwa Adurogbangba, ${ }^{1}$ Xiaofang $\mathbf{M a},{ }^{1,3}$ and Peter Moffett ${ }^{1}$ \\ ${ }^{1}$ Centre SÈVE, Département de Biologie, Université de Sherbrooke, Sherbrooke, Québec, J1K 2R1, Canada; ${ }^{2}$ Current address: \\ Department of Biology, PYD, King Faisal University, Al Hasa, Kingdom of Saudi Arabia; and ${ }^{3}$ College of Plant Science and \\ Technology, Huazhong Agricultural University, Wuhan, Hubei 430070, P. R. China
}

Accepted 19 October 2016.

\begin{abstract}
In plants, RNA silencing regulates gene expression through the action of Dicer-like (DCL) and Argonaute (AGO) proteins via micro RNAs and RNA-dependent DNA methylation (RdDM). In addition, RNA silencing functions as an antiviral defense mechanism by targeting virus-derived double-stranded RNA. Plants encode multiple AGO proteins with specialized functions, including AGO4-like proteins that affect RdDM and AGO2, AGO5, and AGO1, which have antiviral activities. Here, we show that $\mathrm{AGO4}$ is also required for defense against the potexvirus Plantago asiatica mosaic virus (PIAMV), most likely independent of RdDM components such as DCL3, Pol IV, and Pol V. Transient assays showed that AGO4 has direct antiviral activity on PIAMV and, unlike RdDM, this activity does not require nuclear localization of AGO4. Furthermore, although PIAMV infection causes a decrease in $\mathrm{AGO} 4$ expression, PIAMV causes a change in AGO4 localization from a largely nuclear to a largely cytoplasmic distribution. These results indicate an important role for AGO4 in targeting plant RNA viruses as well as demonstrating novel mechanisms of regulation of and by AGO4, independent of its canonical role in regulating gene expression by RdDM.
\end{abstract}

Plants have multiple mechanisms to defend themselves against viruses, including RNA silencing. RNA silencing encompasses a number of related processes that regulate the expression of endogenous genes as well as foreign nucleic acids such as viruses, through the recognition and processing of double-stranded RNA (dsRNA) (Pumplin and Voinnet 2013). The major protein effectors of RNA silencing include Dicer-like (DCL) and Argonaute (AGO) endoribonucleases as well as RNA-dependent RNA polymerases (RDR) (Seo et al. 2013). In Arabidopsis, four different DCL proteins recognize dsRNA and cleave it into short RNA (sRNA) fragments of 21 to $24 \mathrm{nt}$. DCL1 recognizes mainly dsRNA encoded by endogenous transcripts that form hairpins. DCL1 cleaves these precursors into micro RNAs (miRNAs), which are involved in regulating cellular transcripts. DCL2, DCL3, and DCL4 generally recognize longer dsRNA molecules originating from endogenous or exogenous sources and process them into small interfering RNAs (siRNAs) (Axtell 2013; Bologna and Voinnet 2014).

Corresponding author: Peter Moffett; E-mail: peter.moffett@usherbrooke.ca

*The $\boldsymbol{e}$-Xtra logo stands for "electronic extra" and indicates that three supplementary figures and one supplementary table are published online.

This article is in the public domain and not copyrightable. It may be freely reprinted with customary crediting of the source. The American Phytopathological Society, 2016.
After cleavage of dsRNA, sRNAs are incorporated into RNAinduced silencing complexes (RISC). The core RISC activity is carried out by members of the AGO protein family, which bind the sRNAs and use them as guides to target single-stranded RNAs (ssRNAs) with sufficient homology to allow base pairing. In most cases, in plants, this binding results in cleavage of the target ssRNA by the RNase H-like activity of the AGO protein (Borges and Martienssen 2015), although, in some cases, this may result in translational repression, the more common mode of action of AGO proteins in animals (Brodersen et al. 2008). The Arabidopsis genome encodes 10 AGO family members, a number of which show highly specific expression patterns and subcellular localizations, suggesting specialization in function (Borges and Martienssen 2015; Havecker et al. 2010; Mallory and Vaucheret 2010). In particular, members of the AGO4 clade (AGO4, AGO6, AGO9) differ from other family members in that they predominantly localize to the nucleus, in which they bind to 24-nt heterochromatic siRNAs (hcRNAs) corresponding to repetitive elements of the genome (Havecker et al. 2010; Zilberman et al. 2003). These hcRNAs are derived from transcription by RNA Pol V and Pol IV, conversion to dsRNA by RDR2, and dicing by DCL3. AGO4-like proteins then recruit proteins involved in DNA methylation and induce RNA-directed DNA methylation (RdDM), resulting in chromatin modification and alteration of gene expression at specific targeted loci (Matzke et al. 2015). This pathway has been shown to be implicated in plant defense responses by reprogramming host gene expression (Agorio and Vera 2007; Coego et al. 2005; López et al. 2011; Yu et al. 2013).

RNA viruses produce dsRNA as a replication intermediate, thus making them targets of RNA silencing (Harris et al. 2015), mediated largely by DCL2 and DCL4, which generate virusderived siRNAs (vsiRNAs) that can be incorporated into RISC complexes (Andika et al. 2015; Bouché et al. 2006; Brosseau and Moffett 2015; Deleris et al. 2006; Diaz-Pendon et al. 2007; Dunoyer et al. 2007; Garcia-Ruiz et al. 2010; Qu et al. 2008). The resulting "aberrant" viral RNA cleavage products are thought to be substrates for plant RDR proteins, which subsequently generate more dsRNA, thus acting as an amplification cycle (Wang et al. 2010). The major contributors to the production of secondary vsiRNAs are RDR1, RDR2, and RDR6 (Zhang et al. 2015).

Determining which AGO proteins effect defenses against RNA viruses has been the subject of a number of studies. In an in vitro assay AGO1, AGO2, AGO3, and AGO5 all show activity against a tombusvirus and AGO1, AGO2, AGO3, AGO4, AGO5, and AGO9 can bind to sRNAs derived from viroids or viruses (Minoia et al. 2014; Schuck et al. 2013; Takeda et al. 2008; Wang et al. 2011c). These results suggest that multiple AGO proteins have the intrinsic ability to target viruses. Several 
AGO mutants show increased susceptibility to viruses (Carbonell and Carrington 2015) including agol mutants, which are more susceptible to Cucumber mosaic virus (CMV), Turnip crinkle virus (TCV), and Brome mosaic virus (Azevedo et al. 2010; Dzianott et al. 2012; Morel et al. 2002; Qu et al. 2008), and an ago7 mutant shows higher accumulation of certain derivatives of TCV (Qu et al. 2008). AGO2 appears to be a major player in RNA silencing against viruses and has been implicated in defense against CMV, TCV, Tobacco rattle virus (TRV), Potato virus $X$ (PVX), Turnip mosaic virus (TuMV), and Tomato bushy stunt virus (Carbonell et al. 2012; Harvey et al. 2011; Jaubert et al. 2011; Ma et al. 2015; Odokonyero et al. 2015; Scholthof et al. 2011; Wang et al. 2011c; Zhang et al. 2012). In addition, AGO5 appears to play a secondary antiviral role in the absence of AGO2 (Brosseau and Moffett 2015; Garcia-Ruiz et al. 2015) and ago4 mutants are more susceptible to TRV (Fernández-Calvino et al. 2016; Ma et al. 2015).

To counteract RNA silencing, viruses express viral suppressors of RNA silencing (VSRs), which inhibit various aspects of RNA silencing, including the binding of vsiRNAs or interfering with AGO protein function (Csorba et al. 2015; Pumplin and Voinnet 2013). Genetic studies of RNA silencing in virus resistance can be difficult, because compatible interactions between plant and virus necessarily mean that the virus is able to effectively inhibit the plant's defenses. The potexvirus Plantago asiatica mosaic virus (PlAMV) infects Arabidopsis (Yamaji et al. 2012) but moves systemically considerably slower than other Arabidopsis-infecting model RNA viruses, making it a good model for investigating increased susceptibility. Members of the potexvirus family encode for a triple gene block (TGB) of three proteins that are involved in virus movement and establishing replication structures (Kim et al. 2014). The TGB1 or P25 protein of several potexviruses has been shown to have VSR activity (Lim et al. 2010; Senshu et al. 2009; Voinnet et al. 2000). We have previously shown that PVX P25 destabilizes AGO proteins but, also, appears to protect the viral genome from the host cell machinery by creating viral replication complexes (Brosseau and Moffett 2015). The P25 protein of PlAMV inhibits secondary vsiRNA production by targeting the RDR6 pathway (Okano et al. 2014); however, the interaction between PIAMV and AGO proteins has not been reported.

We show an inverse correlation between destabilization of AGO proteins by PlAMV P25 and antiviral activity against PlAMV and that the subset of AGO proteins involved in defense against PlAMV overlaps but differs from those involved in defense against PVX. Surprisingly, ago4 mutant plants display the highest susceptibility to PlAMV, and we present evidence suggesting that AGO4 can target PlAMV RNA. Furthermore, we show that PlAMV infection results in a change in localization of AGO4 from the nucleus to the cytoplasm, suggesting that the susceptibility of ago4 mutant plants is most likely unrelated to the release of AGO4-mediated transcriptional silencing of defense genes. Together with our previous finding that AGO4 is required for resistance to TRV (Ma et al. 2015), this report further establishes a role for $\mathrm{AGO} 4$ in antiviral defense.

\section{RESULTS}

The Arabidopsis AGO4 protein curtails PIAMV infection.

We tested a number of Arabidopsis lines mutated for genes known to be involved in defense, RNA silencing, and DNA methylation for susceptibility to virus (Table 1; Supplementary Table S1). Mutant plants were inoculated with PlAMV expressing green fluorescent protein (PlAMV-GFP) (Yamaji et al. 2012) and their relative susceptibility was assessed visually by the degree and speed of GFP spread throughout the plant, using a scale of one to six plus symbols. Although subjective, this initial survey identified a number of mutants showing obviously increased or decreased susceptibility to PlAMV-GFP. Plants that differed by two plus symbols, more or less, on the visual GFP scale as compared with Col-0 (Fig. 2A) were considered significant. This included the bak1-4 mutant (Heese et al. 2007), a quadruple mutant deficient in four different defense-related hormone signaling pathways (Tsuda et al. 2009), as well as a gh3.2 mutant, which is compromised in auxin signaling and is less susceptible to a necrotrophic fungus (González-Lamothe et al. 2012).

As expected, several RNA silencing mutants were more susceptible to PIAMV, including a triple dicer mutant (triple $d c l$ : $d c l 2 d c l 3 d c l 4)$, which is largely deficient in antiviral RNA silencing (Table 1; Supplementary Fig. S1). Infection of individual ago mutant lines revealed some increased susceptibility in several lines (Table 1). However, in contrast to most previous studies on the requirement for AGO proteins for defense against other RNA viruses, the ago4-2 mutant showed the strongest increase in susceptibility at all time points, with a level of susceptibility to PlAMV similar to the triple dicer mutant (Table 1). To validate the involvement of individual AGO proteins using an alternate approach, we transiently overexpressed PlAMV-GFP with individual Arabidopsis AGO proteins in Nicotiana benthamiana leaves, as previously reported with PVX (Brosseau and Moffett 2015). As seen with PVX, overexpression of AGO2 and AGO5 resulted in lower levels of GFP from PlAMV, as visualized by UV illumination and immunoblotting (Fig. 1A and B). In addition, both AGO3 and AGO4 also restricted PlAMV-GFP accumulation in $N$. benthamiana

Table 1. Qualitative assessment of susceptibility to the potexvirus Plantago asiatica mosaic virus (PlAMV) of Arabidopsis mutants

\begin{tabular}{|c|c|c|c|}
\hline \multirow[b]{2}{*}{ Genotype } & \multicolumn{3}{|c|}{ Degree of susceptibility ${ }^{a}$} \\
\hline & 5 dpi & 10 dpi & 15dpi \\
\hline Col-0 WT & ++ & ++ & +++ \\
\hline agol-27 & + & + & + \\
\hline ago2-1 & +++ & +++ & ++++ \\
\hline ago3-2 & +++ & +++ & ++++ \\
\hline ago4-2 & +++ & +++++ & ++++++ \\
\hline ago4-5 & +++ & ++++ & +++++ \\
\hline ago5-1 & ++ & ++ & +++ \\
\hline ago6-3 & ++ & +++ & ++++ \\
\hline ago7 & ++ & +++ & ++++ \\
\hline ago8-1 & +++ & +++ & ++++ \\
\hline ago8-2 & ++ & ++++ & ++++ \\
\hline ago 9 & ++ & ++++ & ++++ \\
\hline agolo-2 & ++ & +++ & ++++ \\
\hline agol ago2 & + & ++ & ++ \\
\hline agol ago2 agolo & +++ & +++ & nt \\
\hline ago2 ago5 agolo & ++ & +++ & ++++ \\
\hline ago1 ago2 ago7 & ++ & +++ & ++++ \\
\hline dcl2-1 dcl3-1 dcl4-2 & ++ & +++++ & ++++++ \\
\hline dcl1-9 (Ler) & ++ & ++ & +++ \\
\hline dcl3-1 & ++ & +++ & +++ \\
\hline dcl4-2 & ++ & ++++ & +++++ \\
\hline dcl2 dcl4 & ++ & +++++ & ++++++ \\
\hline$r d r 1$ & ++ & +++ & ++++ \\
\hline$r d r 6$ & ++ & ++ & +++ \\
\hline nrpd1 nrpe1 & ++ & nt & ++++ \\
\hline nrpdla-4 & ++ & ++ & ++++ \\
\hline nrpd1b-11 & ++ & ++ & ++++ \\
\hline$n r p d 2 a$ & ++ & ++ & +++ \\
\hline Ler WT & ++ & ++ & +++ \\
\hline ago4-1 (Ler) & ++ & +++ & +++++ \\
\hline
\end{tabular}

Vol. 29, No. 11, 2016 / 879 
leaves (Fig. 1A and B). The PlAMV P25 protein possesses a strong VSR activity in transient assays in $N$. benthamiana (Senshu et al. 2009). The P25 protein of PVX has been shown to destabilize certain AGO proteins (Brosseau and Moffett 2015; Chiu et al. 2010), and therefore, we monitored the accumulation of several Arabidopsis AGO proteins in the presence of PIAMV P25. Several AGO proteins that did not affect PlAMV accumulation in N. benthamiana, including AGO1, AGO6, AGO7, AGO9, and AGO10 showed lower levels of accumulation in the presence of PlAMV P25 (Fig. 1C). This result may explain why these AGO proteins have little or no effect on PIAMV accumulation when overexpressed in $N$. benthamiana. In contrast, AGO2, AGO3, AGO4, and AGO5 protein levels were unaffected by $\mathrm{P} 25$, suggesting that PlAMV is less able to overcome the antiviral activities of these proteins. Given that the AGO4 mutant was significantly more susceptible than all other AGO mutants tested and the fact that AGO4 involvement in defense against RNA viruses has not been extensively studied, we focused further studies on AGO4 antiviral activity.

The ago4-2 mutant allele contains a single missense mutation at amino acid 641. Although this mutation appears to result in a loss of function, it has also been reported to act as a dominant negative over the wild-type (WT) protein (Agorio and Vera 2007), raising the possibility that susceptibility of this line to PlAMV may not result from absence of functional AGO4 but from nonfunctional $\mathrm{AGO} 4$ protein competing for one or more siRNAs, substrates, or partners. We thus infected an additional T-DNA knock-out AGO4 mutant line, namely ago4-5 (CS9927), with PlAMV, and systemic spread of the virus was followed by UV visualization as well as protein and RNA analysis. PlAMVderived GFP was detectable in systemic tissues of both ago4 mutant lines at 7 days postinoculation (dpi) but not in Col-0 (Fig. $2 \mathrm{~A}$ ). However, there was a noticeable difference in resistance to PlAMV between these two mutants wherein ago4-2 displayed higher susceptibility, manifested as visibly greater GFP accumulation, higher PIAMV coat protein $(\mathrm{CP})$ and RNA accumulation in systemic leaves at both 7 and 9 dpi as well as more severe symptoms at 21 dpi (Fig. 2A, B, C, and D). A similar increased susceptibility to PlAMV was seen with the ago4-1 null allele in the Ler background (Supplementary Fig. S2). As several AGO proteins appear to be implicated in restricting PIAMV, the increased susceptibility observed in ago4-2 compared with the ago4-5 mutant may be caused by dominant negative function of this mutated AGO4 protein. Nevertheless, AGO4 also appears to be required, per se, to curtail PlAMV infection in both Col- 0 and Ler backgrounds.

\section{PIAMV infection reduces AGO4 accumulation.}

Several genes encoding AGO proteins implicated in antiviral and antibacterial defense responses have been shown to be

A
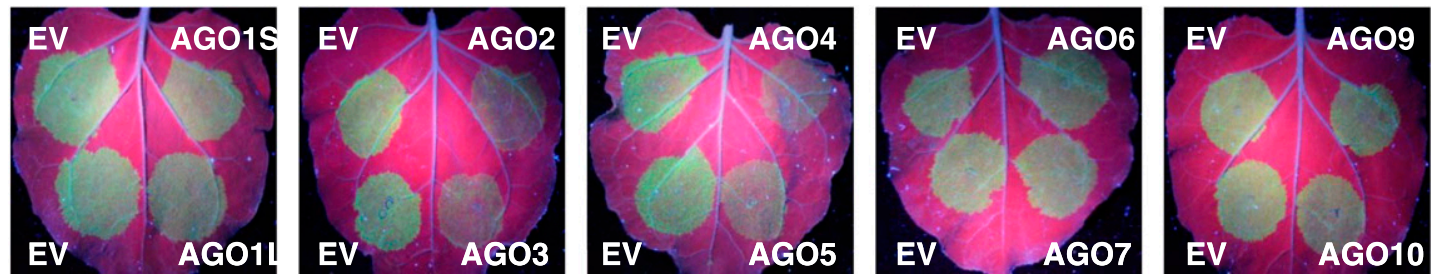

B
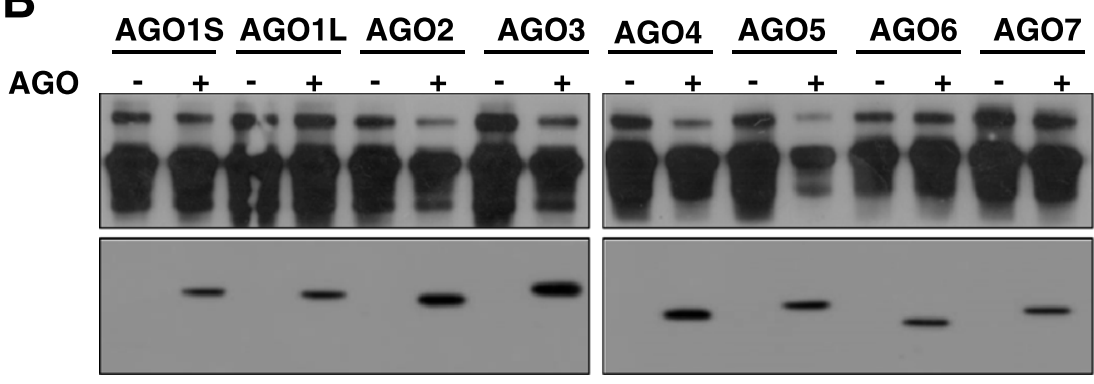

AG09 AG010

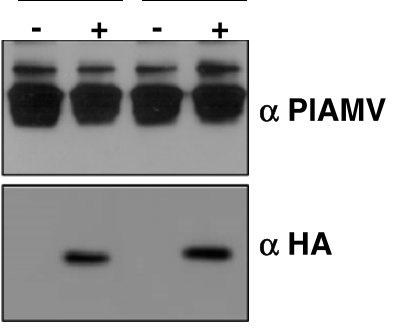

C
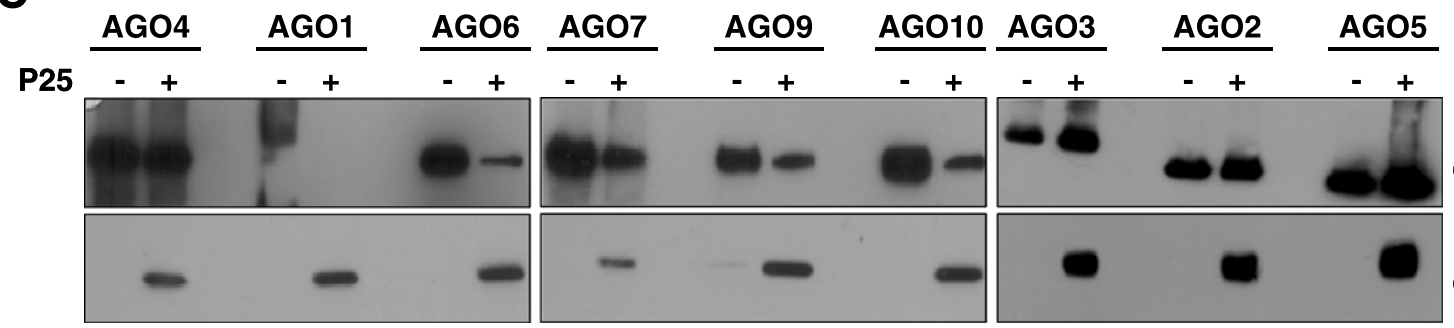

$\alpha$ HA

$\alpha$ FLAG

Fig. 1. Multiple Arabidopsis Argonaute (AGO) proteins compromise the potexvirus Plantago asiatica mosaic virus (PlAMV) accumulation in Nicotiana benthamiana. A, $N$. benthamiana leaves were agroinfiltrated with PlAMV expressing green fluorescent protein along with hemagglutinin (HA)-tagged Arabidopsis AGO proteins or empty vector (EV), as indicated. Leaves were photographed under UV illumination 4 days postinoculation (dpi). B, Total protein extracts were prepared from $N$. benthamiana leaves agroinfiltrated as in A but at 3 dpi and subjected to sodium dodecyl sulfate-polyacrylamide gel electrophoresis, followed by anti-PIAMV coat protein immunoblotting (top panel). + indicates the presence of the indicated AGO protein and - indicates EV. HA-tagged AGO proteins were immunoprecipitated from the same extracts and were subjected to anti-HA immunoblotting (lower panel). C, HA-tagged AGO proteins were coexpressed by agroinfiltration in $N$. benthamiana leaves with either FLAG-tagged P25 (+) or with empty vector (-). Total proteins were extracted and subjected to anti-FLAG immunoblotting (bottom panel). HA-tagged AGO proteins were immunoprecipitated and subjected to anti-HA immunoblotting (top panel). Experiments were performed three times and a representative result is shown. 
induced upon pathogen infection (Brosseau and Moffett 2015; Harvey et al. 2011; Várallyay et al. 2010; Wu et al. 2015; Zhang et al. 2011). We thus examined AGO4 protein levels upon PlAMV infection by immunoblotting. PlAMV infection resulted in a marked decrease in AGO4 protein accumulation in local inoculated leaves (Fig. 3A). AGO4 levels were also repressed in systemic leaves at $8 \mathrm{dpi}$ (Fig. 3A). At this time point, PlAMV is visible only in a relatively small portion of systemic leaves, suggesting that this downregulation may be non-cell autonomous.

Since the PlAMV P25 protein did not compromise the accumulation of AGO4 (Fig. 1C), we hypothesized that this regulation could be mediated, at least in part, at the transcriptional level. Therefore, we monitored $A G O 4$ expression by quantitative reverse transcription-polymerase chain reaction (qRT-PCR) analysis. Consistent with protein levels, AGO4 transcripts were significantly less abundant after PlAMV infection in both local and systemic leaves (Fig. 3B).
Long-term restriction of PIAMV requires mainly DCL2- and DCL4-derived siRNAs.

AGO4 is known to preferentially bind 24-nt hcRNAs derived from the plant genome to form RdDM effector complexes (Gao et al. 2010; Havecker et al. 2010; He et al. 2009; Mi et al 2008; Wang et al. 2011a). However, when expressed in the presence of a viroid, AGO4 binds mostly to 21- and 22-nt viroid-derived siRNAs (Minoia et al. 2014). Previous reports have demonstrated that both DCL2- and DCL4-produced sRNAs are required for optimal defense against ssRNA viruses (Andika et al. 2015; Bouché et al. 2006; Brosseau and Moffett 2015; Deleris et al. 2006; Diaz-Pendon et al. 2007; Dunoyer et al. 2007; Garcia-Ruiz et al. 2010; Qu et al. 2008). However, AGO4 has been shown to predominantly bind hcsiRNAs produced by DCL3 and to function in RdDM (Havecker et al. 2010; Zilberman et al. 2003). To investigate whether AGO4 antiviral activity is related to its function in endogenous gene regulation,

$\mathbf{E}$
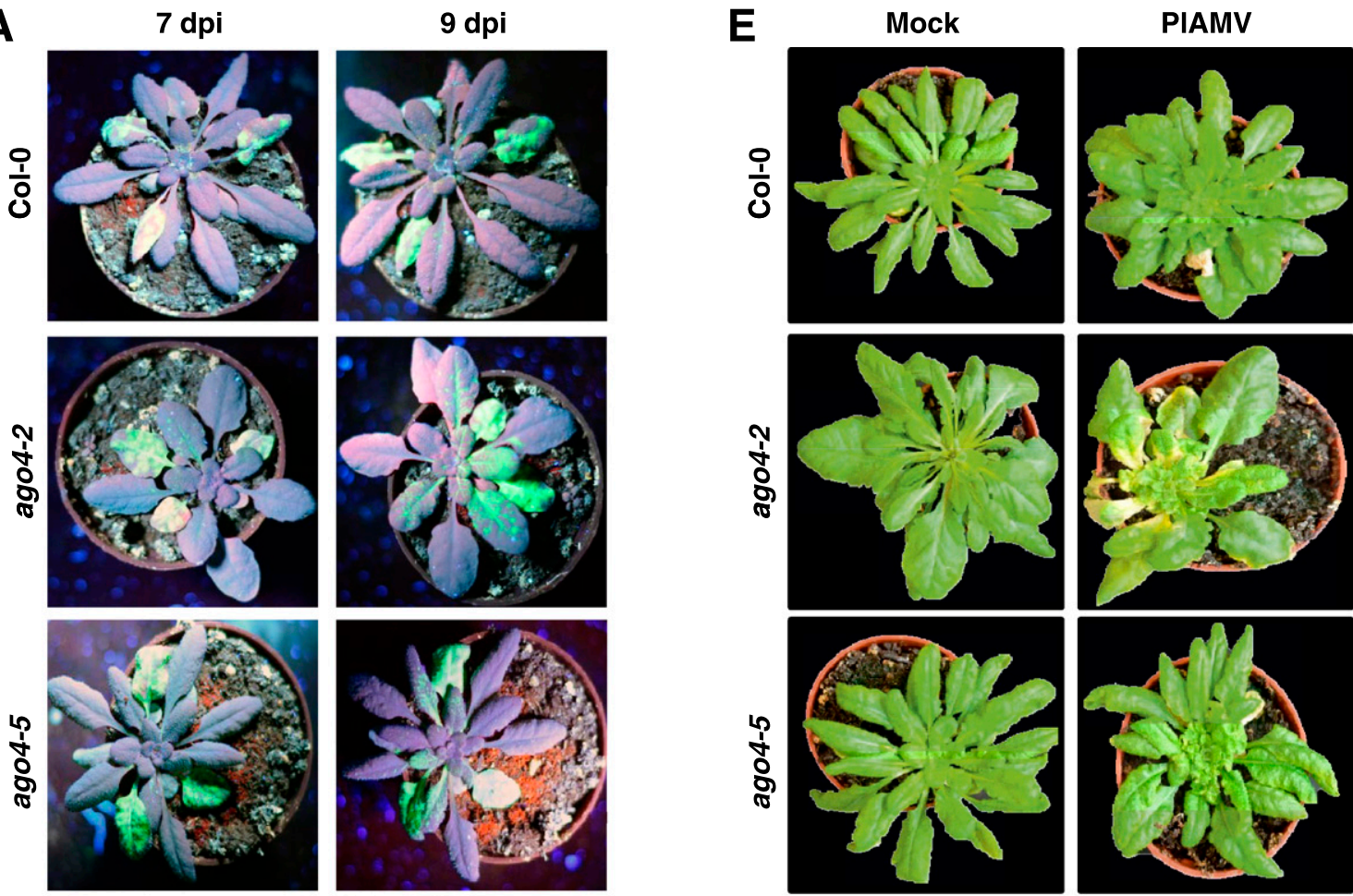
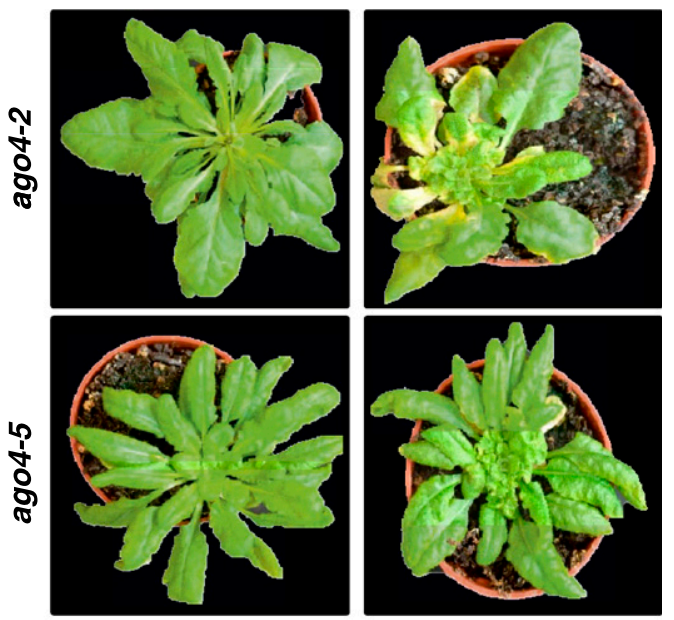

B

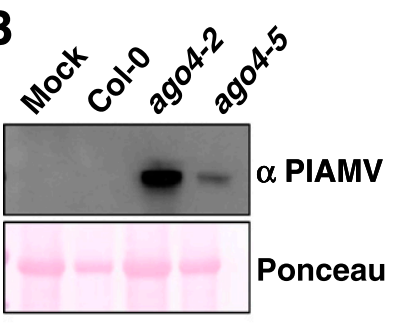

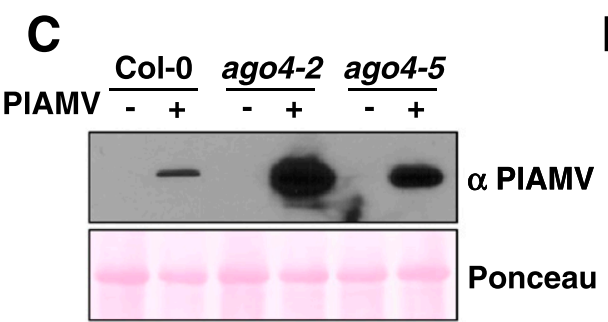

Fig. 2. AGO4 knock-out lines display enhanced susceptibility to the potexvirus Plantago asiatica mosaic virus (PIAMV). A, wild-type (WT) Col-0 Arabidopsis or AGO4 mutant lines, as indicated, were inoculated with PlAMV expressing green fluorescent protein (PIAMV-GFP). Plants were photographed under UV illumination at 7 and 9 days postinoculation (dpi). B and $\mathbf{C}$, At 7 and 9 dpi, respectively, total protein extracts were prepared from systemic leaves and were subjected to sodium dodecyl sulfate-polyacrylamide gel electrophoresis, followed by anti-PlAMV coat protein immunoblotting (top panel). Ponceau staining (bottom panel) of the same extracts is shown to demonstrate equal loading. Three plants per genotype were tested in each experiment and the experiment was repeated five times. D, At 8 dpi, total RNA was extracted from Col-0 WT, ago4-2, or ago4-5 mutant plants infected with PlAMV-GFP and was subjected to Northern blotting with an anti-GFP probe. PlAMV subgenomic (sg) RNAs are indicated. Ethidium bromide (EtBr)-stained RNA is shown to demonstrate equal loading. The experiment was repeated three times and a representative result is shown. E, WT Col-0 Arabidopsis or ago4 mutant lines were either mockinoculated or inoculated with PIAMV-GFP. Plants were photograph at 21 dpi. 
we followed PlAMV infection in different $d c l$ and $n r p d$ mutants. At $8 \mathrm{dpi}$, the $d c l 1$ mutation did not appear to result in accelerated movement of PlAMV into systemic leaves and, at this time point, WT and $d c l l$ mutants display similar accumulation of virus in systemic leaves, as judged visually and by anti-PlAMV CP immunoblotting (Fig. 4A and B). Although single $d c l 3$ or $d c l 4$ mutants appeared slightly more susceptible than Col-0, they were nonetheless less susceptible than the ago4-2 mutant. Indeed, only double $d c l 2 ~ d c l 4$ and triple $d c l$ mutants were as susceptible as ago4-2, suggesting that optimal defense against PlAMV mainly depends on DCL2- and DCL4derived sRNAs in early infection (Fig. 4A and B). However, at

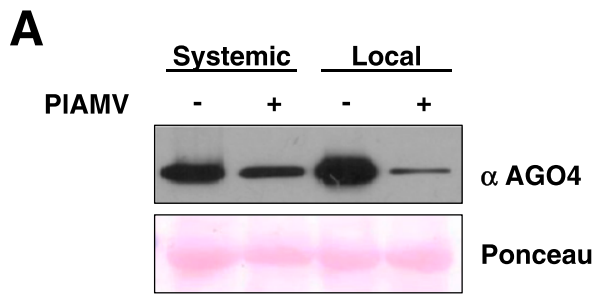

B

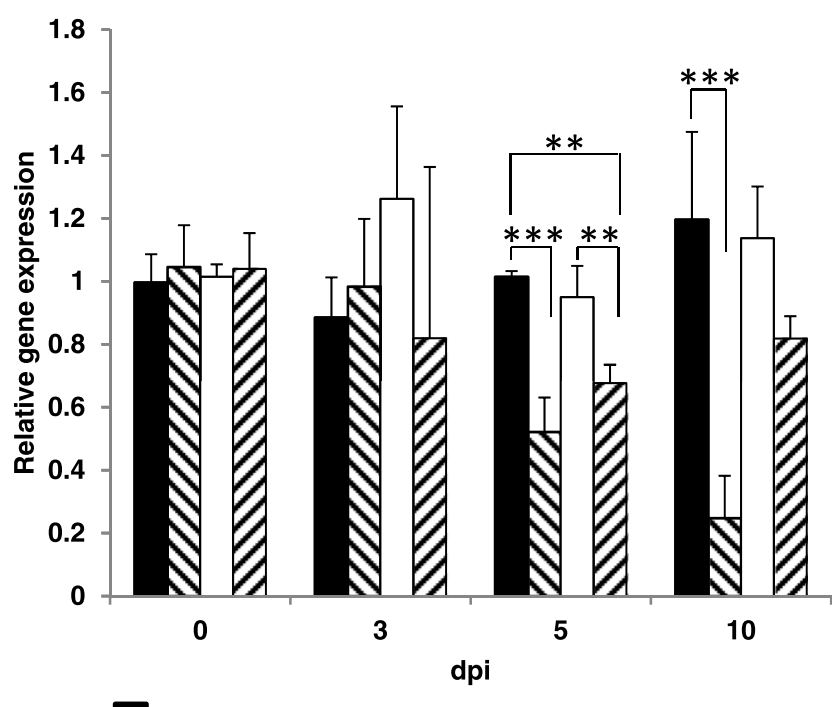

Mock-inoculated leaves

Leaves inoculated with PIAMV-GFP

Systemic leaves from mock-inoculated leaves

Systemic leaves from PIAMV-GFP inoculated plants

Fig. 3. The potexvirus Plantago asiatica mosaic virus (PlAMV) infection compromises AGO4 accumulation. Col-0 Arabidopsis were either mockinoculated or inoculated with PlAMV expressing green fluorescent protein (PlAMV-GFP). A, At 8 days postinoculation (dpi), total protein extracts were prepared from inoculated or systemic leaves and were subjected to sodium dodecyl sulfate-polyacrylamide gel electrophoresis, followed by anti-AGO4 immunoblotting (top panel). Ponceau staining (bottom panel) of the same extracts is shown, to demonstrate equal loading. Experiments were performed three times with similar results. B, Total RNA was extracted from inoculated and systemic leaves at indicated time points and was subjected to quantitative reverse transcription-polymerase chain reaction analysis to determine relative expression levels of AGO4. Relative gene expressions were analyzed using one-way analysis of variance. Error bars represent standard deviation from three biological replicates. Data sets marked with asterisks are significantly different from mock-inoculated plants at the same time point, as assessed by Tukey's studentized range test (honest significant difference): triple asterisks (***) indicate $P<0.01$ or double asterisks (**) $P<0.05$. The experiment was repeated at least three times with similar results.
21 dpi, mutation of DCLA alone appears to be sufficient to induce severe PIAMV symptoms, whereas DCL3 appears to be dispensable for optimal defense against PIAMV (Supplementary Fig. S3). Consistent with this observation, mutants of the NRPDI $a, N R P D 1 b$, or NRPD2a genes, whose products encode subunits of the Pol IV and Pol V complexes that are required for generating 24-nt hcRNAs, did not behave like ago4 mutants, as judged by PlAMV CP accumulation at 9 dpi (Fig. 4C), although the $n r p d 2 a$ mutant showed a slight increase in CP at 9 dpi (Fig. 4C) and more severe symptoms at $21 \mathrm{dpi}$. Taken together, these results suggest that the antiviral function of AGO4 is independent of the canonical RdDM mechanism associated with AGO4-mediated epigenetic regulation, namely DCL3 and polymerases Pol IV and Pol V.

AGO4 antiviral activity takes place in the cytoplasm.

As canonical antiviral silencing mechanisms but not RdDM appear to be involved in the response to PIAMV, we hypothesized that AGO4 may function in the cytoplasm, the presumed location of PlAMV. To test this possibility, AGO4 was transiently expressed in $N$. benthamiana leaves in the presence or absence of PlAMV and the cytoplasmic/nuclear distribution of hemagglutinin (HA)-tagged AGO4 was monitored by preparing cytoplasmic and nuclear fractions, followed by anti-HA immunoblotting to detect HA-AGO4. As previously reported (Ye et al. 2012), in the absence of PlAMV, AGO4 is distributed in both the cytoplasm and the nucleus but with a majority of the protein present in the nucleus (Fig. 5A). However, when coexpressed with PlAMV, AGO4 was still present in both cell compartments but with a larger portion of the protein present in the cytoplasm (Fig. 5A). In agreement with the transient assays with $\mathrm{P} 25$, total AGO4 protein accumulation was not altered by coexpression with PIAMV (Fig. 1C). Transgenic Arabidopsis expressing AGO4 fused to enhanced GFP (eGFP) expressed from the AGO4 promoter (Ye et al. 2012) do not accumulate sufficient levels of GFP-AGO4 to allow visualization in leaves. However, this construct does allow sufficient accumulation in transient expression in $N$. benthamiana leaves to allow us to monitor cellular distribution by confocal microscopy. As previously reported, in the absence of virus, AGO4 showed a clear nuclear localization ( $\mathrm{Li}$ et al. 2006; Pontes et al. 2006; Ye et al. 2012). However, consistent with the results obtained by biochemical fractionation, coexpression of PIAMV with GFP-AGO4 resulted in a shift toward a dispersed cytoplasmic localization of AGO4 (Fig. 5B).

The alteration of AGO4 localization could be due to sequestration by PlAMV or could be an active mechanism induced as a plant defense response. We, thus, transiently expressed PlAMVGFP with WT AGO4 or a version of AGO4 lacking its nuclear localization signal (AGO4 $\triangle \mathrm{NLS}$ ) expressed from the AGO4 genomic promoter (Ye et al. 2012). In this assay, although AGO4 $\triangle$ NLS was expressed beyond the limit of detection (Fig. $6 \mathrm{~B})$, both versions of AGO4 were equally efficient at reducing PlAMV-GFP accumulation (Fig. 6A and B). These results suggest that AGO4 antiviral activity is achieved through mechanisms similar to those used by other AGO proteins and strongly suggest that the antiviral action of $\mathrm{AGO} 4$ is mediated in the cytoplasm.

\section{DISCUSSION}

Previous studies have suggested that the AGO2 and AGO1 proteins play roles in defense against a range of RNA viruses (Carbonell and Carrington 2015), although agol mutants often show increased resistance against viruses such as TRV, TuMV, PVX (Brosseau and Moffett 2015; Garcia-Ruiz et al. 2015; Ma et al. 2015) and PIAMV (Table 1). AGO4 has been shown to contribute to defense against plant DNA viruses by targeting 
their genomes for methylation (Raja et al. 2008 2014). Through its predominant localization in the nucleus and its involvement in transcriptional gene silencing (TGS) and RdDM (Gao et al. 2010; Greenberg et al. 2011; Li et al. 2006; Wierzbicki et al. 2008; Ye et al. 2012; Zilberman et al. 2003), the antiviral action of AGO4 against DNA viruses is intuitive. However, an involvement of AGO4 in counteracting RNA viruses has not been well-described. Although VSRs such as CMV $2 b$ have been shown to inhibit AGO4 activity and the TRV 16K protein binds to AGO4 (Fernández-Calvino et al. 2016; Hamera et al. 2012), the significance of these results is not clear. VSR targets may not always be specific, due to mechanisms that broadly target RNA silencing components (i.e., broadly targeting most or all AGO proteins or sRNAs). Indeed, increased susceptibility of ago4 mutants has only been reported for one RNA virus, TRV (Fernández-Calvino et al. 2016; Ma et al. 2015). AGO4 has been previously shown to be required for defense against biotrophic pathogens, as well as for nucleotide binding-leucinerich repeat-mediated defenses, presumably through its role in gene regulation (Agorio and Vera 2007; Bhattacharjee et al. 2009; Dowen et al. 2012; Hamera et al. 2012). Although, as suggested by Hamera et al. (2012), it is possible that AGO4 is involved in the transcriptional response to virus infection, our study and other recent reports suggest an alternate mechanism for AGO4 antiviral activity.

\section{AGO4 possesses antiviral function independent of the RdDM pathway.}

Several studies have shown widespread dynamic differential methylation in response to pathogen infection and it has been suggested that altered susceptibility to nonviral pathogens in ago4 mutants may be due to the role of AGO4 in DNA methylation (Dowen et al. 2012; Hamera et al. 2012; López et al.
2011; Yu et al. 2013). However, in the case of PlAMV, the defense response is most likely not entirely at the transcriptional level. First, genetic analysis indicates that DCL3 does not play a major role in resistance to PlAMV (Fig. 4A and B). This suggests that $\mathrm{AGO} 4$ antiviral activity does not involve the canonical TGS activity mediated by DCL3-produced 24-nt sRNAs, although we cannot rule out the possibility of TGS mediation through association of AGO4 with 21- or 22-nt sRNA. Secondly, both nuclear/cytoplasmic fractionation and microscopy analysis showed that AGO4 is predominantly localized in the cytoplasm upon PlAMV infection (Fig. 5). These results suggest that AGO4 acts against viruses in the cytoplasm rather than through $\mathrm{RdDM}$, which takes place in the nucleus (Gao et al. 2010; Li et al. 2006; Wierzbicki et al. 2008). Although the remaining AGO4 protein present in the nucleus could be sufficient to induce transcriptional changes to restrict PlAMV, we favor a cytoplasmic mode of action because expression of AGO4 $\triangle$ NLS also restricts PlAMV (Fig. 6). Furthermore, the observation that mutation of different genes in the RdDM pathway does not lead to the same increase in susceptibility as the ago4 mutants indicates that AGO4 antiviral function against PlAMV is at least partially independent of RdDM (Table 1; Fig. 4C).

Plants deficient in salicylic acid (SA) signaling (pad4) are more susceptible to PlAMV, while plants constitutively activated in SA signaling (sncl) (Li et al. 2001) are more resistant, consistent with studies showing an involvement of SA in defense against viruses (Chivasa et al. 1997; Lee et al. 2011; Murphy et al. 1999). Whether AGO4, SA, and BAK1-mediated defenses are related remains to be seen, although if AGO4 were a downstream component of pathogen-associated molecular patterntriggered immunity or SA signaling, it would be expected to be required for resistance against other viruses. However, whereas
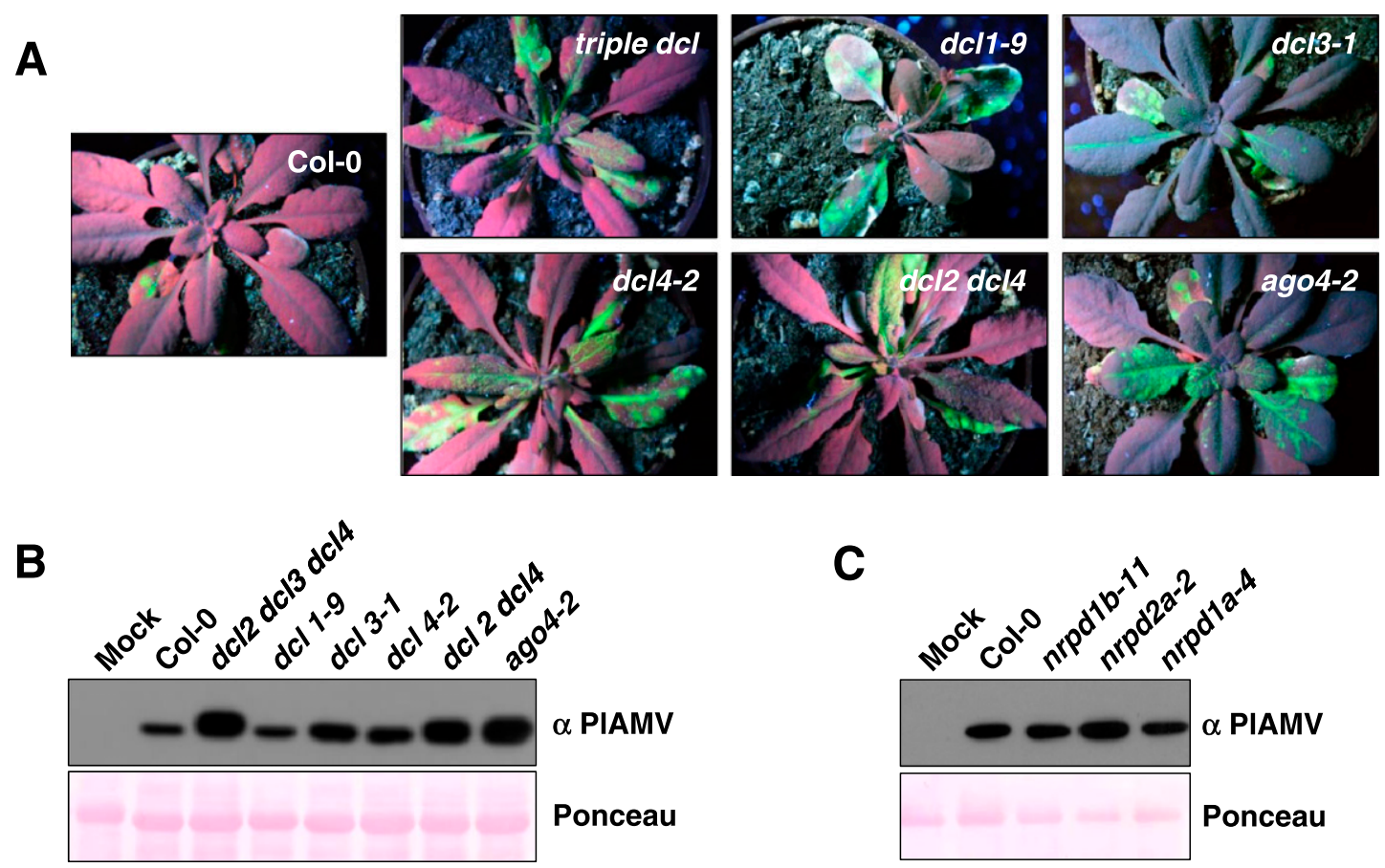

Fig. 4. Early defense against the potexvirus Plantago asiatica mosaic virus (PIAMV) requires DCL2 and DCL4 but not RNA-dependent DNA methylation (RdDM) components. Col-0 wild-type Arabidopsis as well as single, double, or triple $d c l$ mutant lines, as indicated, were inoculated with PlAMV expressing green fluorescent protein (PlAMV-GFP). A, Plants were photographed under UV illumination at 8 days postinoculation (dpi). B, At 8 dpi, total protein extracts were prepared from systemic leaves and were subjected to sodium dodecyl sulfate-polyacrylamide gel electrophoresis (SDS-PAGE), followed by anti-PIAMV coat protein immunoblotting (top panel). Ponceau staining (bottom panel) of the same extracts is shown to demonstrate equal loading. C, The indicated RdDM mutants were inoculated with PlAMV-GFP. At 9 dpi, total protein extracts were prepared from systemic leaves and were subjected to SDS-PAGE, followed by anti-PlAMV coat protein immunoblotting (top panel). Ponceau staining (bottom panel) of the same extracts is shown to demonstrate equal loading. Three plants per genotype were tested in each experiment and the experiment was repeated four times. 
plants deficient in SA are more susceptible to VSR-deficient CMV, ago4 mutants are not (Shang et al. 2011; Wang et al. 2011c). Likewise, bakl but not ago4 mutants show increased susceptibility to TCV (Kørner et al. 2013; Zhang et al. 2012). Thus, we suggest that the specificity in requirement for AGO4 is consistent with the differential requirement for other AGO proteins reported for other plant-virus interactions. That is, different AGO proteins contribute to virus resistance depending on the ability of the virus to counteract their activity as well as their ability to access viral RNA.

\section{AGO4 expression and localization.}

The increased presence of AGO4 in the cytoplasm versus the nucleus in the presence of PIAMV could be due either to a direct effect of the virus on AGO4 or an indirect effect. A previous study has shown that the localization of the RNA

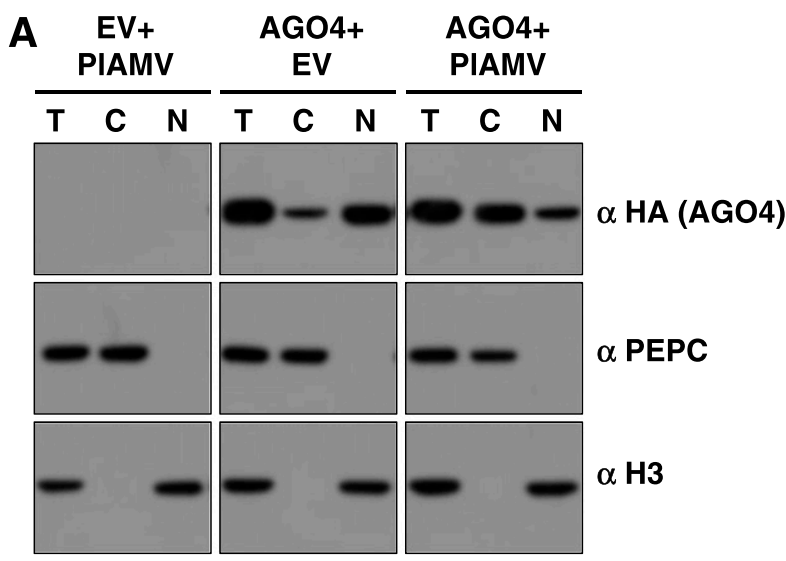

B
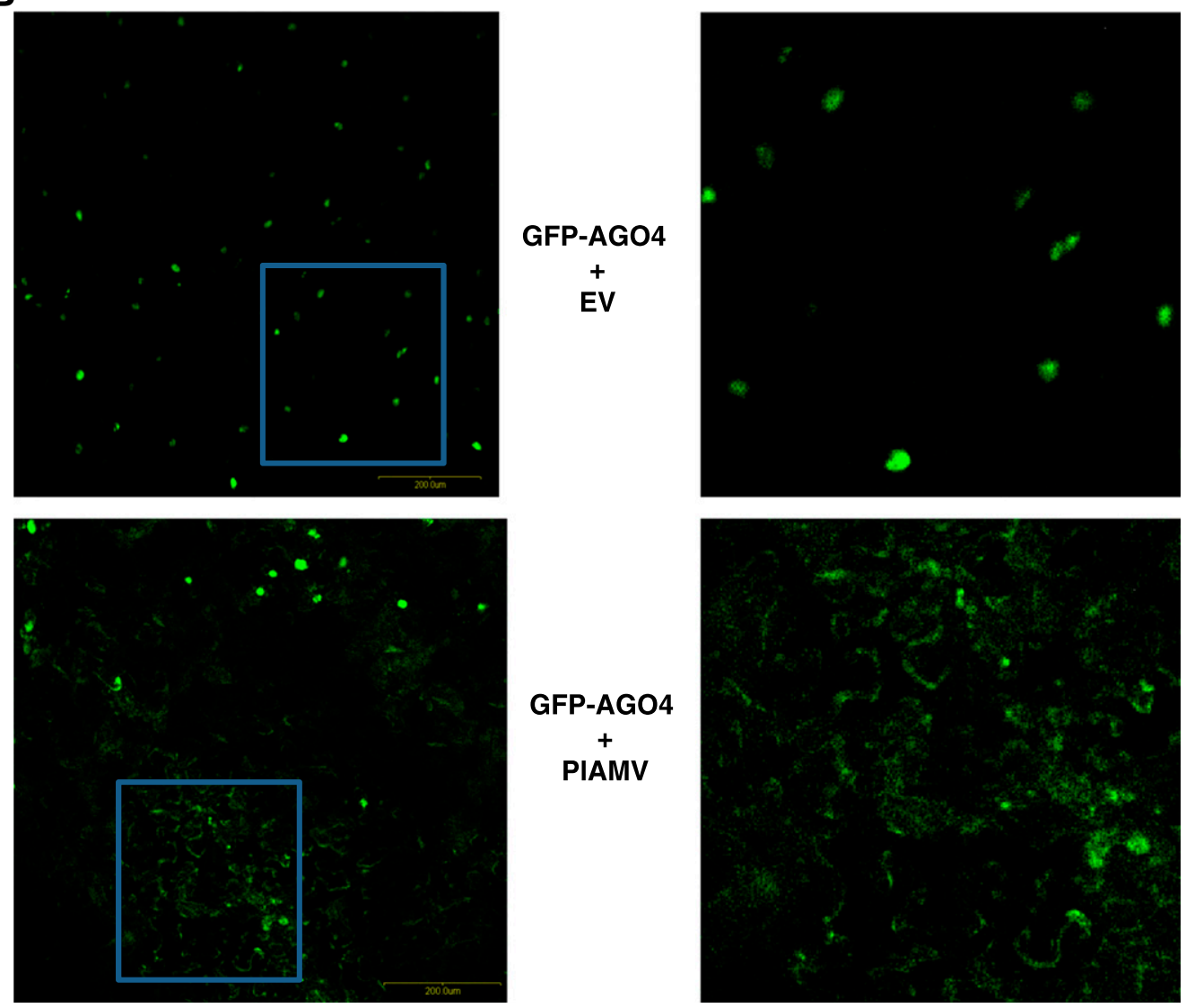

Fig. 5. A portion of the AGO4 pool is redistributed to the cytoplasm during Plantago asiatica mosaic virus (PIAMV) infection. A, Hemagglutinin-tagged (HA) AGO4 protein was coexpressed by agroinfiltration in Nicotiana benthamiana leaves with either empty vector (EV) or PIAMV expressing green fluorescent protein (PlAMV), as indicated. At 3 days postinoculation (dpi), total protein extracts (T) were prepared as well as cytoplasmic (C) and nuclear (N) fractions. These fractions were then subjected to sodium dodecyl sulfate-polyacrylamide gel electrophoresis followed by anti-AGO4 HA immunoblotting (top panel). Anti-PEPC immunoblotting (middle panel) was used as protein marker for the cytoplasmic fraction, and anti-histone H3 immunoblotting (bottom panel) was used as a nuclear marker. B, $\mathrm{P}_{\mathrm{AGO} 4}$ :eGFP-AGO4 was coexpressed by agroinfiltration in $N$. benthamiana leaves with either EV or PlAMV. At 3 dpi, eGFPAGO4 fluorescence was observed by confocal microscopy. The boxed areas in the left panels are shown as close-ups in the right panels. The experiments were repeated at least three times with similar results. 
silencing component SGS3 is altered by the PIAMV VSR P25 (Okano et al. 2014). In this case, P25 appears to enwrap SGS3 bodies in localized cytoplasmic foci and curtails their ability to generate secondary siRNAs. However, AGO4 does not appear to localize to specific foci in the presence of PIAMV (Fig. 5) and is, thus, not likely affected in the same way as SGS3. Likewise, AGO4 function does not appear to be compromised by PIAMV, as AGO4 coexpression with PlAMV restricts virus accumulation and AGO4 stability is not affected by P25 (Figs. 1 and 5A). Thus the effect of PlAMV on AGO4 localization may be indirect. This effect is not likely due to AGO4 overexpression, as GFP-AGO4 localization, in our experiments (Fig. 5B), appears to be the same as when it is expressed from the AGO4 promoter in transgenic plants (Ye et al. 2012). The nature of this effect will require further study, as the nuclear localization of AGO4 is affected by several factors, including cytoplasmic loading of siRNAs, cleavage activity, and Hsp90 function (Ye et al. 2012). The increased cytoplasmic localization of AGO4 could be due to an inhibition of AGO4 loading of 24-nt sRNAs. However, this seems unlikely, as PlAMV P25 transgenic plants show compromised accumulation of 21-nt, most likely secondary siRNA, but not 24-nt, sRNAs (Okano et al. 2014). Alternatively, the movement of AGO4 out of the nucleus may be an active defense response on the part of the plant. In this scenario, we hypothesize that the plant cell responds to the presence of virus and localizes AGO4 to the cytoplasm, where it directly targets viral RNA. Although we do not see a difference in overall AGO4 accumulation in the presence of PlAMV (Fig. 1B, Fig. 5A), the GFP-AGO4 $\triangle$ NLS protein was not detectable, suggesting that its inability to transit to the nucleus may result in low levels of accumulation. However, most plant AGO proteins intrinsically accumulate to very low levels, requiring concentration by immunoprecipitation to detect by immunoblotting (discussed below), and GFP-AGO4 $\triangle$ NLS still had a clear effect on PlAMV (Fig. 6).

Interestingly, our results demonstrate that, even if AGO4 is required to restrict PlAMV, its expression decreases during the course of infection (Fig. 3). This downregulation does not appear to be age-related as mock-infected plants do not show a similar decrease over time (Fig. 3B). This is consistent with a previous study showing that $A G O 4$ is downregulated in $N$. benthamiana in response to PVX infection (Ye et al. 2009). AGO4 downregulation does not appear to be virus-specific, as it is also downregulated in response to flagellin detection and infection by Pseudomonas syringae (Yu et al. 2013). Whether this phenomenon is induced by the pathogen to increase susceptibility or if it is a decision of the plant to shift toward other defense pathways is not clear. It is interesting to note, however, that both the induction of AGO5 expression (Brosseau and Moffett 2015) and the downregulation of AGO4 (Fig. 3) occur in systemic leaves before widespread infection of PlAMV in these tissues. For example, AGO4 protein levels are decreased in systemic leaves at $5 \mathrm{dpi}$ (Fig. 3A), whereas PlAMV-GFP is still not visibly detectable in systemic leaves at 7 or $8 \mathrm{dpi}$ (Figs. 2A and 4A). Indeed, when transiently expressed from a constitutive promoter, AGO4 protein levels are not affected by the presence of PlAMV. This suggests that AGO4 levels may be affected by PlAMV infection at the transcriptional or post-transcriptional level and that a systemic signal may be involved.

\section{Virus defense and counter defense.}

A direct action of AGO4 on virus resistance may seem counterintuitive, as it is best characterized for its role in epigenetic regulation (Matzke et al. 2015). However, we have shown that all Arabidopsis AGO proteins have the intrinsic ability to target PVX lacking its TGB proteins, presumably because the viral RNAs are not protected by either a VSR or viral replication complexes induced by these proteins (Brosseau and Moffett 2015). Likewise, most AGO proteins, including AGO4, can bind to 21- and 24-nt sRNAs derived from viroids and overexpression of AGO1, AGO2, AGO4, and AGO5 attenuates viroid accumulation (Minoia et al. 2014). This leads us to suggest that the requirement for different AGO proteins for defense against viruses may depend on the properties or replication strategies of the virus in question (Brosseau and Moffett 2015; Ma et al. 2015). To be able to target a virus, a given AGO protein must not be inhibited by a VSR but must, also, be able to access viral RNA. In agreement with this, only those AGO proteins not destabilized by the P25 show activity against PlAMV (Fig. 1). Mutants of those AGO proteins that do target PlAMV in transient assays do not all show phenotypes, however, probably because the strong activity of AGO4 masks their contribution. We note that the number of AGO proteins targeting PVX (AGO2 and AGO5) is less than those targeting PlAMV (AGO2, AGO3, AGO4, and AGO5) and speculate that this is due to a combination of VSR targeting specificity and RNA accessibility, the latter due to differences in viral replication complexes. The increased susceptibility of PlAMV to AGO proteins, however, may be less important, given that its P25 strongly suppresses the production of secondary siRNAs by the SGS3/RDR6 pathway, whereas PVX P25 does not (Okano et al. 2014).

This report further underscores the importance of using both functional and genetic approaches to understanding antiviral RNA silencing and solidifies the involvement of AGO4 in resistance to at least some viruses. In addition, our observation of the alteration of AGO4 localization suggests both an explanation for how this presumed nuclear protein functions in combating viruses in the cytoplasm and paves the way for future work aimed at understanding this phenomenon.

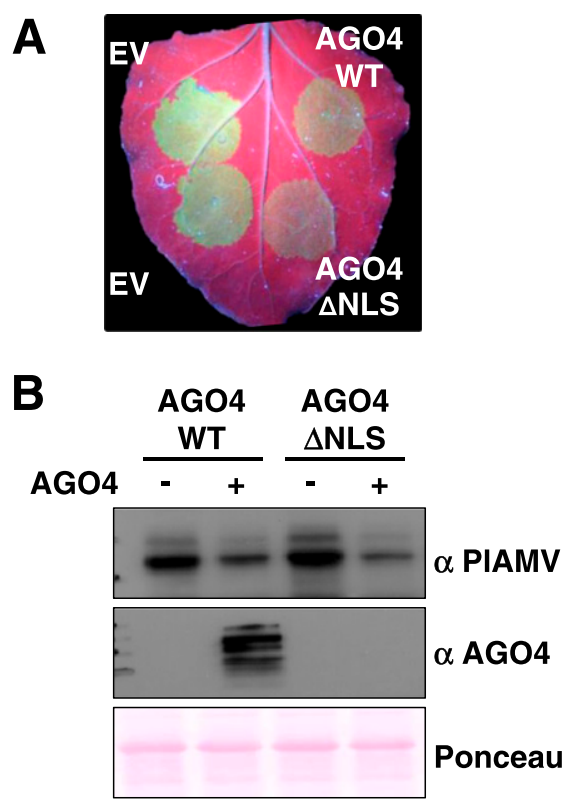

Fig. 6. AGO4 antiviral activity against the potexvirus Plantago asiatica mosaic virus (PlAMV) takes place in the cytoplasm. A, Nicotiana benthamiana leaves were agroinfiltrated with PlAMV expressing green fluorescent protein along with either empty vector (EV) or $\mathrm{P}_{\mathrm{AGO} 4}$ :eGFP-AGO4 wild type or $\mathrm{P}_{\mathrm{AGO} 4}$ : eGFP-AGO4 $\triangle$ NLS. Leaves were photographed under UV illumination, 4 days postinoculation (dpi). B, At 4 dpi, total protein extracts were prepared from $N$. benthamiana leaves agroinfiltrated as in A and subjected to sodium dodecyl sulfate-polyacrylamide gel electrophoresis, followed by anti-PIAMV coat protein (top panel) or anti-AGO4 (middle panel) immunoblotting. Ponceau staining (bottom panel) of the same extracts is shown to demonstrate equal loading. The experiment was repeated at least three times with similar results. 


\section{MATERIALS AND METHODS}

Plant material and growth conditions.

Nicotiana benthamiana and Arabidopsis thaliana plants were grown in BM6 (Berger) and Agromix (Fafard), respectively, in growth chambers with 16-h-light and 8-h-dark and 12-h-light and 8-h-dark photoperiods at 23 and $21^{\circ} \mathrm{C}$, respectively. Except for the ago4-5 mutant line (ABRC CS9927), all Arabidopsis mutant lines have been described previously, including agol-27 (Morel et al. 2002), ago2-1, ago3-1, ago6-3, ago8-1, ago10-2 (Takeda et al. 2008), ago5-1, ago7, ago9 (Katiyar-Agarwal et al. 2007), ago4-1 (Zilberman et al. 2003), ago4-2 (Agorio and Vera 2007), agol ago2, agol ago2 ago7, ago2 ago7, ago2 ago5 ago10, agol ago2 ago10 (Wang et al. 2011c), triple dicer (Deleris et al. 2006), dcl1-9 (Jacobsen et al. 1999), dcl2-1, dcl3-1 (Xie et al. 2004), dcl4-2, dcl2 dcl4 (Xie et al. 2005), rdrl-1 (Xie et al. 2004), rdr6-15 (Boccara et al. 2014), nrpd2a (López et al. 2011), nrpdla-4, nrpdlb-11, and nrpdl nrpel (Pontier et al. 2005).

\section{Plasmid construction.}

For the generation of pBIN61-P25-FLAG, the P25 coding sequence was amplified with primers 5 '-tctagaATGGACA TAGTCATCTCAGC- $3^{\prime}$ and $5^{\prime}$-ggatccGTAGGTGGGGTGAG$3^{\prime}$, using PlAMV-GFP (Yamaji et al. 2012) as template. All other constructions have been previously described, including pBIC-HA-AtAGO constructs (Takeda et al. 2008), PlAMVGFP (Yamaji et al. 2012), PlAMV (Ozeki et al. 2006), pAGO4: GFP-AGO4, and its $\triangle$ NLS variant (Ye et al. 2012).

\section{Virus inoculation in A. thaliana.}

Infections of three-week-old Arabidopsis plants were carried out by rub-inoculation as previously described (Brosseau and Moffett 2015), except that the inoculum was diluted 1:4 in phosphate buffer (i.e., $8 \mathrm{ml}$ per gram of infected tissues).

\section{Transient expression in $N$. benthamiana.}

Agrobacterium-mediated transient expression assays in $N$. benthamiana were performed as previously described (Brosseau and Moffett 2015).

\section{RNA analysis.}

Northern blotting was performed as previously described, using a GFP probe (Ma et al. 2015). For RT-qPCR analysis, total RNA was extracted from leaf samples, using the RNeasy plant mini kit according to the manufacturer's recommendation (Qiagen). RNAs were treated with RNAase free DNAase (Qiagen). First-strand cDNA was synthesized from $2 \mu \mathrm{g}$ of total RNA, using Superscript II reverse transcription (Invitrogen). The AGO4 gene was amplified using the following primers: AtAGO4F, TGA GGC ATT ACC ACC TCC TC and AtAGO4R, CGA GCC ATA GGA ACT CGA AC. qPCR was performed as previously described (El Oirdi et al. 2011; González-Lamothe et al. 2012) with some modifications, using the Eva Green method according to the manufacturer's recommendation (BioRad). Melting curves were determined using the dissociation curve software operated by CFX Manager software (version 3.0) to ensure that only a single product was amplified. The Biorad CFX96 real-time PCR system (Bio-Rad) operated by CFX Manager software (version 3.0) was used to detect the amplification level and was programmed with an initial step of $98^{\circ} \mathrm{C}$ for 2 min and 40 cycles of $98^{\circ} \mathrm{C}$ for $2 \mathrm{~s}$ and annealing/extension at $60^{\circ} \mathrm{C}$ for $5 \mathrm{~s}$, with melt curve analyses from 65 to $95^{\circ} \mathrm{C}$ in $0.5^{\circ} \mathrm{C}$ increments. All reactions were run in technical triplicates for each biological replicate, and the average values were used for quantification. The relative quantification of target genes was determined using the threshold cycle $(\mathrm{Ct})$ method. Briefly, the $\mathrm{Ct}$ values of target genes were normalized to an endogenous control gene $(\mathrm{Ct}=\mathrm{Ct}$ target $-\mathrm{Ct}$ endogenous) and were compared with a calibrator $(\mathrm{Ct}=\mathrm{Ct}$ sample - Ct calibrator). Relative expression (RQ) was calculated using the BioRad sequence detection system software and the formula $\mathrm{RQ}=2-\mathrm{Ct}$.

AtEF1 was used as an endogenous control for plant target, using the following primers: AtEF1 $\alpha$ F, TCTCCGAGTACC CACCTTTG and AtEF1 $\alpha$ R, TCCTTCTTGTCCACGCTCTT.

\section{Statistical analysis.}

Relative gene expressions were analyzed using one-way analysis of variance. Error bars represent standard deviation from three biological replicates. Data sets marked with asterisks are significantly different from WT plants at the same time point, as assessed by Tukey's studentized range test (honest significant difference) $(* * *$ indicate $P<0.01$ or $* * P<0.05)$. The experiment was repeated at least three times with similar results.

\section{Protein extraction and analysis.}

For AGO expression analysis, $1 \mathrm{~g}$ of fresh tissue was ground into $2 \mathrm{ml}$ of RISC buffer ( $20 \mathrm{mM}$ Tris- $\mathrm{HCl}$ [pH 7.5], $150 \mathrm{mM}$ $\mathrm{NaCl}, 5 \mathrm{mM} \mathrm{MgCl}_{2}, 5 \mathrm{mM}$ dithiothreitol [DTT], 0.5\% NP-40) supplemented with protease inhibitor cocktail. Total protein extracts were centrifuged at $16,000 \times g$ for $10 \mathrm{~min}$ at $4^{\circ} \mathrm{C}$. A fraction of total protein extract was kept for detection of PlAMV. Immunoprecipitation was carried out with $1.4 \mathrm{ml}$ of supernatant and $25 \mu$ l of $\mathrm{HA}$-agarose beads (Sigma) for $2 \mathrm{~h}$ at $4^{\circ} \mathrm{C}$ on a rotatory shaker. Beads were washed four times with RISC buffer. After centrifugation, beads were resuspended in $50 \mu$ l of $1.5 \times$ of Laemmli loading buffer. Proteins were separated by sodium dodecyl sulfate-polyacrylamide gel electrophoresis (SDS-PAGE) on 7.5 or $10.5 \%$ acrylamide gels for AGO or GFP and CP detection, respectively, and were transferred to a polyvinylidene difluoride membrane (Bio-Rad) by electroblotting. HA-AGO proteins were probed with anti-HA-horseradish peroxidase conjugated (HRP) antibodies (Sigma; 1:3,000 dilution). Detection of GFP was carried out by probing membranes with anti-GFP-HRP antibodies (Santa Cruz, 1:3,000 dilution). AntiPlAMV-CP rabbit polyclonal antibodies (Agdia, 1:20,000 dilution) were used to detect PlAMV, followed by donkey anti-IgG rabbit-HRP polyclonal antibodies (BioLegend, 1:10,000 dilution). Detection of Arabidopsis AGO4 was carried out by probing membranes with anti-AGO4 antibody (Agrisera, 1:4000 dilution) and subsequently with donkey anti-IgG rabbit-HRP polyclonal antibodies (BioLegend, 1:10,000 dilution).

\section{Nuclear-cytoplasmic fractionation.}

Nuclear/cytoplasmic fractionation was performed as previously described (Wang et al. 2011b), with minor modifications. AGO4 present in cytoplasmic fraction was concentrated by immunoprecipitation. The purified nuclear pellets were homogenized in Trizol to extract proteins, as per the manufacturer's instructions (Ambion).

\section{Confocal microscopy.}

Three days after agroinfiltration, leaf discs from infiltrated patches were mounted between a slide and coverslip and GFPAGO4 fluorescence was monitored with a $20 \times$ objective, using a $488 \mathrm{~nm}$ argon laser. Emitted fluorescence was collected using a 510 to 530 band-pass filter and a 575 to 630 band pass on an Olympus FV300 confocal microscope.

\section{ACKNOWLEDGMENTS}

We are grateful to S. Namba for PlAMV constructs, to Y. Qi for eGFPAGO4 constructs, to K. Bouarab for mutant Arabidopsis lines, and to D. Garneau for assistance with confocal microscopy analysis. This work 
was supported by funding from the National Science and Engineering Council (Canada) and the Fonds de Recherche du Québec, Nature et Technologie (FRQNT) to P. Moffett, by a scholarship from the Chinese Scholarship Council to $\mathrm{X}$. Ma, and by a graduate fellowship from the Natural Sciences and Engineering Research Council of Canada Collaborative Research and Training Experience Agrophytosciences program to A. Adurogbangba.

\section{LITERATURE CITED}

Agorio, A., and Vera, P. 2007. ARGONAUTE4 is required for resistance to Pseudomonas syringae in Arabidopsis. Plant Cell 19:3778-3790.

Andika, I. B., Maruyama, K., Sun, L., Kondo, H., Tamada, T., and Suzuki, N. 2015. Differential contributions of plant Dicer-like proteins to antiviral defences against potato virus $\mathrm{X}$ in leaves and roots. Plant J. 81:781-793.

Axtell, M. J. 2013. Classification and comparison of small RNAs from plants. Annu. Rev. Plant Biol. 64:137-159.

Azevedo, J., Garcia, D., Pontier, D., Ohnesorge, S., Yu, A., Garcia, S., Braun, L., Bergdoll, M., Hakimi, M. A., Lagrange, T., and Voinnet, O. 2010. Argonaute quenching and global changes in Dicer homeostasis caused by a pathogen-encoded GW repeat protein. Genes Dev. 24:904-915.

Bhattacharjee, S., Zamora, A., Azhar, M. T., Sacco, M. A., Lambert, L. H., and Moffett, P. 2009. Virus resistance induced by NB-LRR proteins involves Argonaute4-dependent translational control. Plant J. 58:940-951.

Boccara, M., Sarazin, A., Thiebeauld, O., Jay, F., Voinnet, O., Navarro, L., and Colot, V. 2014. The Arabidopsis miR472-RDR6 silencing pathway modulates PAMP- and effector-triggered immunity through the posttranscriptional control of disease resistance genes. PLoS Pathog 10:e1003883.

Bologna, N. G., and Voinnet, O. 2014. The diversity, biogenesis, and activities of endogenous silencing small RNAs in Arabidopsis. Annu. Rev. Plant Biol. 65:473-503.

Borges, F., and Martienssen, R. A. 2015. The expanding world of small RNAs in plants. Nat. Rev. Mol. Cell Biol. 16:727-741.

Bouché, N., Lauressergues, D., Gasciolli, V., and Vaucheret, H. 2006. An antagonistic function for Arabidopsis DCL2 in development and a new function for DCL4 in generating viral siRNAs. EMBO J. 25:3347-3356.

Brodersen, P., Sakvarelidze-Achard, L., Bruun-Rasmussen, M., Dunoyer, P., Yamamoto, Y. Y., Sieburth, L., and Voinnet, O. 2008. Widespread translational inhibition by plant miRNAs and siRNAs. Science 320:1185-1190.

Brosseau, C., and Moffett, P. 2015. Functional and genetic analysis identify a role for Arabidopsis ARGONAUTE5 in antiviral RNA silencing. Plant Cell 27:1742-1754.

Carbonell, A., and Carrington, J. C. 2015. Antiviral roles of plant ARGONAUTES. Curr. Opin. Plant Biol. 27:111-117.

Carbonell, A., Fahlgren, N., Garcia-Ruiz, H., Gilbert, K. B., Montgomery, T. A., Nguyen, T., Cuperus, J. T., and Carrington, J. C. 2012. Functional analysis of three Arabidopsis ARGONAUTES using slicer-defective mutants. Plant Cell 24:3613-3629.

Chiu, M. H., Chen, I. H., Baulcombe, D. C., and Tsai, C. H. 2010. The silencing suppressor P25 of Potato virus X interacts with Argonaute1 and mediates its degradation through the proteasome pathway. Mol. Plant Pathol. 11:641-649.

Chivasa, S., Murphy, A. M., Naylor, M., and Carr, J. P. 1997. Salicylic acid interferes with tobacco mosaic virus replication via a novel salicylhydroxamic acid-sensitive mechanism. Plant Cell 9:547-557.

Coego, A., Ramirez, V., Gil, M. J., Flors, V., Mauch-Mani, B., and Vera, P. 2005. An Arabidopsis homeodomain transcription factor, OVEREXPRESSOR OF CATIONIC PEROXIDASE 3, mediates resistance to infection by necrotrophic pathogens. Plant Cell 17:2123-2137.

Csorba, T., Kontra, L., and Burgyan, J. 2015. Viral silencing suppressors: Tools forged to fine-tune host-pathogen coexistence. Virology 479-480:85-103.

Deleris, A., Gallego-Bartolome, J., Bao, J., Kasschau, K. D., Carrington, J. C., and Voinnet, O. 2006. Hierarchical action and inhibition of plant Dicer-like proteins in antiviral defense. Science 313:68-71.

Diaz-Pendon, J. A., Li, F., Li, W. X., and Ding, S. W. 2007. Suppression of antiviral silencing by cucumber mosaic virus $2 \mathrm{~b}$ protein in Arabidopsis is associated with drastically reduced accumulation of three classes of viral small interfering RNAs. Plant Cell 19:2053-2063.

Dowen, R. H., Pelizzola, M., Schmitz, R. J., Lister, R., Dowen, J. M., Nery, J. R., Dixon, J. E., and Ecker, J. R. 2012. Widespread dynamic DNA methylation in response to biotic stress. Proc. Natl. Acad. Sci. U.S.A. 109:E2183-E2191.

Dunoyer, P., Himber, C., Ruiz-Ferrer, V., Alioua, A., and Voinnet, O. 2007. Intra- and intercellular RNA interference in Arabidopsis thaliana requires components of the microRNA and heterochromatic silencing pathways. Nat. Genet. 39:848-856.

Dzianott, A., Sztuba-Solińska, J., and Bujarski, J. J. 2012. Mutations in the antiviral RNAi defense pathway modify Brome mosaic virus RNA recombinant profiles. Mol. Plant-Microbe Interact. 25:97-106.
El Oirdi, M., El Rahman, T. A., Rigano, L., El Hadrami, A., Rodriguez, M. C., Daayf, F., Vojnov, A., and Bouarab, K. 2011. Botrytis cinerea manipulates the antagonistic effects between immune pathways to promote disease development in tomato. Plant Cell 23:2405-2421.

Fernández-Calvino, L., Martínez-Priego, L., Szabo, E. Z., Guzmán-Benito, I., González, I., Canto, T., Lakatos, L., and Llave, C. 2016. Tobacco rattle virus $16 \mathrm{~K}$ silencing suppressor binds ARGONAUTE 4 and inhibits formation of RNA silencing complexes. J. Gen. Virol. 97:246-257.

Gao, Z., Liu, H. L., Daxinger, L., Pontes, O., He, X., Qian, W., Lin, H., Xie, M., Lorkovic, Z. J., Zhang, S., Miki, D., Zhan, X., Pontier, D., Lagrange, T., Jin, H., Matzke, A. J., Matzke, M., Pikaard, C. S., and Zhu, J. K. 2010. An RNA polymerase II- and AGO4-associated protein acts in RNAdirected DNA methylation. Nature 465:106-109.

Garcia-Ruiz, H., Carbonell, A., Hoyer, J. S., Fahlgren, N., Gilbert, K. B., Takeda, A., Giampetruzzi, A., Garcia Ruiz, M. T., McGinn, M. G., Lowery, N., Martinez Baladejo, M. T., and Carrington, J. C. 2015. Roles and programming of Arabidopsis ARGONAUTE proteins during Turnip mosaic virus infection. PLoS Pathog. 11:e1004755.

Garcia-Ruiz, H., Takeda, A., Chapman, E. J., Sullivan, C. M., Fahlgren, N., Brempelis, K. J., and Carrington, J. C. 2010. Arabidopsis RNAdependent RNA polymerases and dicer-like proteins in antiviral defense and small interfering RNA biogenesis during Turnip mosaic virus infection. Plant Cell 22:481-496.

González-Lamothe, R., El Oirdi, M., Brisson, N., and Bouarab, K. 2012. The conjugated auxin indole-3-acetic acid-aspartic acid promotes plant disease development. Plant Cell 24:762-777.

Greenberg, M. V., Ausin, I., Chan, S. W., Cokus, S. J., Cuperus, J. T., Feng, S., Law, J. A., Chu, C., Pellegrini, M., Carrington, J. C., and Jacobsen, S. E. 2011. Identification of genes required for de novo DNA methylation in Arabidopsis. Epigenetics 6:344-354.

Hamera, S., Song, X., Su, L., Chen, X., and Fang, R. 2012. Cucumber mosaic virus suppressor $2 \mathrm{~b}$ binds to AGO4-related small RNAs and impairs AGO4 activities. Plant J. 69:104-115.

Harris, C. J., Molnar, A., Müller, S. Y., and Baulcombe, D. C. 2015. FDF-PAGE A powerful technique revealing previously undetected small RNAs sequestered by complementary transcripts. Nucleic Acids Res. 43:7590-7599.

Harvey, J. J., Lewsey, M. G., Patel, K., Westwood, J., Heimstädt, S., Carr, J. P., and Baulcombe, D. C. 2011. An antiviral defense role of AGO2 in plants. PLoS One 6:e14639.

Havecker, E. R., Wallbridge, L. M., Hardcastle, T. J., Bush, M. S., Kelly, K. A., Dunn, R. M., Schwach, F., Doonan, J. H., and Baulcombe, D. C 2010. The Arabidopsis RNA-directed DNA methylation argonautes functionally diverge based on their expression and interaction with target loci. Plant Cell 22:321-334.

He, X. J., Hsu, Y. F., Zhu, S., Wierzbicki, A. T., Pontes, O., Pikaard, C. S., Liu, H. L., Wang, C. S., Jin, H., and Zhu, J. K. 2009. An effector of RNAdirected DNA methylation in arabidopsis is an ARGONAUTE 4- and RNA-binding protein. Cell 137:498-508.

Heese, A., Hann, D. R., Gimenez-Ibanez, S., Jones, A. M., He, K., Li, J., Schroeder, J. I., Peck, S. C., and Rathjen, J. P. 2007. The receptor-like kinase SERK3/BAK1 is a central regulator of innate immunity in plants. Proc. Natl. Acad. Sci. U.S.A. 104:12217-12222.

Jacobsen, S. E., Running, M. P., and Meyerowitz, E. M. 1999. Disruption of an RNA helicase/RNAse III gene in Arabidopsis causes unregulated cell division in floral meristems. Development 126:5231-5243.

Jaubert, M., Bhattacharjee, S., Mello, A. F., Perry, K. L., and Moffett, P. 2011. ARGONAUTE2 mediates RNA-silencing antiviral defenses against Potato virus $X$ in Arabidopsis. Plant Physiol. 156:1556-1564.

Katiyar-Agarwal, S., Gao, S., Vivian-Smith, A., and Jin, H. 2007. A novel class of bacteria-induced small RNAs in Arabidopsis. Genes Dev 21 3123-3134.

Kim, Y. J., Maizel, A., and Chen, X. 2014. Traffic into silence: Endomembranes and post-transcriptional RNA silencing. EMBO J. 33:968-980.

Kørner, C. J., Klauser, D., Niehl, A., Domínguez-Ferreras, A., Chinchilla, D., Boller, T., Heinlein, M., and Hann, D. R. 2013. The immunity regulator BAK1 contributes to resistance against diverse RNA viruses. Mol. Plant-Microbe Interact. 26:1271-1280.

Lee, W. S., Fu, S. F., Verchot-Lubicz, J., and Carr, J. P. 2011. Genetic modification of alternative respiration in Nicotiana benthamiana affects basal and salicylic acid-induced resistance to potato virus X. BMC Plant Biol. 11:41.

Li, C. F., Pontes, O., El-Shami, M., Henderson, I. R., Bernatavichute, Y. V., Chan, S. W., Lagrange, T., Pikaard, C. S., and Jacobsen, S. E. 2006. An ARGONAUTE4-containing nuclear processing center colocalized with Cajal bodies in Arabidopsis thaliana. Cell 126:93-106.

Li, X., Clarke, J. D., Zhang, Y., and Dong, X. 2001. Activation of an EDS1mediated $R$-gene pathway in the sncl mutant leads to constitutive, NPR1-independent pathogen resistance. Mol. Plant-Microbe Interact. 14:1131-1139. 
Lim, H. S., Vaira, A. M., Domier, L. L., Lee, S. C., Kim, H. G., and Hammond, J. 2010. Efficiency of VIGS and gene expression in a novel bipartite potexvirus vector delivery system as a function of strength of TGB1 silencing suppression. Virology 402:149-163.

López, A., Ramírez, V., García-Andrade, J., Flors, V., and Vera, P. 2011. The RNA silencing enzyme RNA polymerase $\mathrm{v}$ is required for plant immunity. PLoS Genet. 7:e1002434.

Ma, X., Nicole, M. C., Meteignier, L. V., Hong, N., Wang, G., and Moffett, P. 2015. Different roles for RNA silencing and RNA processing components in virus recovery and virus-induced gene silencing in plants. J. Exp. Bot. 66:919-932.

Mallory, A., and Vaucheret, H. 2010. Form, function, and regulation of ARGONAUTE proteins. Plant Cell 22:3879-3889.

Matzke, M. A., Kanno, T., and Matzke, A. J. 2015. RNA-directed DNA methylation: The evolution of a complex epigenetic pathway in flowering plants. Annu. Rev. Plant Biol. 66:243-267.

Mi, S., Cai, T., Hu, Y., Chen, Y., Hodges, E., Ni, F., Wu, L., Li, S., Zhou, H., Long, C., Chen, S., Hannon, G. J., and Qi, Y. 2008. Sorting of small RNAs into Arabidopsis argonaute complexes is directed by the 5' terminal nucleotide. Cell 133:116-127.

Minoia, S., Carbonell, A., Di Serio, F., Gisel, A., Carrington, J. C., Navarro, B., and Flores, R. 2014. Specific argonautes selectively bind small RNAs derived from potato spindle tuber viroid and attenuate viroid accumulation in vivo. J. Virol. 88:11933-11945.

Morel, J. B., Godon, C., Mourrain, P., Béclin, C., Boutet, S., Feuerbach, F., Proux, F., and Vaucheret, H. 2002. Fertile hypomorphic ARGONAUTE (agol) mutants impaired in post-transcriptional gene silencing and virus resistance. Plant Cell 14:629-639.

Murphy, A. M., Chivasa, S., Singh, D. P., and Carr, J. P. 1999. Salicylic acid-induced resistance to viruses and other pathogens: A parting of the ways? Trends Plant Sci. 4:155-160.

Odokonyero, D., Mendoza, M. R., Alvarado, V. Y., Zhang, J., Wang, X., and Scholthof, H. B. 2015. Transgenic down-regulation of ARGONAUTE2 expression in Nicotiana benthamiana interferes with several layers of antiviral defenses. Virology 486:209-218.

Okano, Y., Senshu, H., Hashimoto, M., Neriya, Y., Netsu, O., Minato, N., Yoshida, T., Maejima, K., Oshima, K., Komatsu, K., Yamaji, Y., and Namba, S. 2014. In planta recognition of a double-stranded RNA synthesis protein complex by a potexviral RNA silencing suppressor. Plant Cell 26:2168-2183.

Ozeki, J., Takahashi, S., Komatsu, K., Kagiwada, S., Yamashita, K., Mori, T., Hirata, H., Yamaji, Y., Ugaki, M., and Namba, S. 2006. A single amino acid in the RNA-dependent RNA polymerase of Plantago asiatica mosaic virus contributes to systemic necrosis. Arch. Virol. 151:2067-2075.

Pontes, O., Li, C. F., Costa Nunes, P., Haag, J., Ream, T., Vitins, A., Jacobsen, S. E., and Pikaard, C. S. 2006. The Arabidopsis chromatinmodifying nuclear siRNA pathway involves a nucleolar RNA processing center. Cell 126:79-92.

Pontier, D., Yahubyan, G., Vega, D., Bulski, A., Saez-Vasquez, J., Hakimi, M. A., Lerbs-Mache, S., Colot, V., and Lagrange, T. 2005. Reinforcement of silencing at transposons and highly repeated sequences requires the concerted action of two distinct RNA polymerases IV in Arabidopsis. Genes Dev. 19:2030-2040.

Pumplin, N., and Voinnet, O. 2013. RNA silencing suppression by plant pathogens: Defence, counter-defence and counter-counter-defence. Nat. Rev. Microbiol. 11:745-760.

Qu, F., Ye, X., and Morris, T. J. 2008. Arabidopsis DRB4, AGO1, AGO7, and RDR6 participate in a DCL4-initiated antiviral RNA silencing pathway negatively regulated by DCL1. Proc. Natl. Acad. Sci. U.S.A. 105:14732-14737.

Raja, P., Jackel, J. N., Li, S., Heard, I. M., and Bisaro, D. M. 2014. Arabidopsis double-stranded RNA binding protein DRB3 participates in methylationmediated defense against geminiviruses. J. Virol. 88:2611-2622.

Raja, P., Sanville, B. C., Buchmann, R. C., and Bisaro, D. M. 2008. Viral genome methylation as an epigenetic defense against geminiviruses. J. Virol. 82:8997-9007.

Scholthof, H. B., Alvarado, V. Y., Vega-Arreguin, J. C., Ciomperlik, J., Odokonyero, D., Brosseau, C., Jaubert, M., Zamora, A., and Moffett, P. 2011. Identification of an ARGONAUTE for antiviral RNA silencing in Nicotiana benthamiana. Plant Physiol. 156:1548-1555.

Schuck, J., Gursinsky, T., Pantaleo, V., Burgyán, J., and Behrens, S. E. 2013. AGO/RISC-mediated antiviral RNA silencing in a plant in vitro system. Nucleic Acids Res. 41:5090-5103.

Senshu, H., Ozeki, J., Komatsu, K., Hashimoto, M., Hatada, K., Aoyama M., Kagiwada, S., Yamaji, Y., and Namba, S. 2009. Variability in the level of RNA silencing suppression caused by triple gene block protein 1 (TGBp1) from various potexviruses during infection. J. Gen. Virol. 90: 1014-1024.
Seo, J. K., Wu, J., Lii, Y., Li, Y., and Jin, H. 2013. Contribution of small RNA pathway components in plant immunity. Mol. Plant-Microbe Interact. 26:617-625.

Shang, J., Xi, D. H., Xu, F., Wang, S. D., Cao, S., Xu, M. Y., Zhao, P. P., Wang, J. H., Jia, S. D., Zhang, Z. W., Yuan, S., and Lin, H. H. 2011. A broadspectrum, efficient and nontransgenic approach to control plant viruses by application of salicylic acid and jasmonic acid. Planta 233:299-308.

Takeda, A., Iwasaki, S., Watanabe, T., Utsumi, M., and Watanabe, Y. 2008 The mechanism selecting the guide strand from small RNA duplexes is different among argonaute proteins. Plant Cell Physiol. 49:493-500.

Tsuda, K., Sato, M., Stoddard, T., Glazebrook, J., and Katagiri, F. 2009 Network properties of robust immunity in plants. PLoS Genet. 5: e1000772.

Várallyay, E., Válóczi, A., Agyi, A., Burgyán, J., and Havelda, Z. 2010. Plant virus-mediated induction of miR168 is associated with repression of ARGONAUTE1 accumulation. EMBO J. 29:3507-3519.

Voinnet, O., Lederer, C., and Baulcombe, D. C. 2000. A viral movement protein prevents spread of the gene silencing signal in Nicotiana benthamiana. Cell 103:157-167.

Wang, H., Zhang, X., Liu, J., Kiba, T., Woo, J., Ojo, T., Hafner, M., Tuschl, T., Chua, N. H., and Wang, X. J. 2011a. Deep sequencing of small RNAs specifically associated with Arabidopsis AGO1 and AGO4 uncovers new AGO functions. Plant J. 67:292-304

Wang, W., Ye, R., Xin, Y., Fang, X., Li, C., Shi, H., Zhou, X., and Qi, Y. 2011 b. An importin $\beta$ protein negatively regulates microRNA activity in Arabidopsis. Plant Cell 23:3565-3576.

Wang, X. B., Jovel, J., Udomporn, P., Wang, Y., Wu, Q., Li, W. X., Gasciolli, V., Vaucheret, H., and Ding, S. W. 2011c. The 21-nucleotide, but not 22-nucleotide, viral secondary small interfering RNAs direct potent antiviral defense by two cooperative Argonautes in Arabidopsis thaliana. Plant Cell 23:1625-1638.

Wang, X. B., Wu, Q., Ito, T., Cillo, F., Li, W. X., Chen, X., Yu, J. L., and Ding, S. W. 2010. RNAi-mediated viral immunity requires amplification of virus-derived siRNAs in Arabidopsis thaliana. Proc. Natl. Acad. Sci. U.S.A. 107:484-489.

Wierzbicki, A. T., Haag, J. R., and Pikaard, C. S. 2008. Noncoding transcription by RNA polymerase Pol IVb/Pol V mediates transcriptional silencing of overlapping and adjacent genes. Cell 135:635-648.

Wu, J., Yang, Z., Wang, Y., Zheng, L., Ye, R., Ji, Y., Zhao, S., Ji, S., Liu, R., Xu, L., Zheng, H., Zhou, Y., Zhang, X., Cao, X., Xie, L., Wu, Z., Qi, Y., and Li, Y. 2015. Viral-inducible Argonaute18 confers broad-spectrum virus resistance in rice by sequestering a host microRNA. eLife 4: e05733.

Xie, Z., Allen, E., Wilken, A., and Carrington, J. C. 2005. DICER-LIKE 4 functions in trans-acting small interfering RNA biogenesis and vegetative phase change in Arabidopsis thaliana. Proc. Natl. Acad. Sci. U.S.A. 102:12984-12989.

Xie, Z., Johansen, L. K., Gustafson, A. M., Kasschau, K. D., Lellis, A. D., Zilberman, D., Jacobsen, S. E., and Carrington, J. C. 2004. Genetic and functional diversification of small RNA pathways in plants. PLoS Biol. 2:e104.

Yamaji, Y., Maejima, K., Ozeki, J., Komatsu, K., Shiraishi, T., Okano, Y., Himeno, M., Sugawara, K., Neriya, Y., Minato, N., Miura, C., Hashimoto, M., and Namba, S. 2012. Lectin-mediated resistance impairs plant virus infection at the cellular level. Plant Cell 24:778-793.

Ye, J., Qu, J., Zhang, J. F., Geng, Y. F., and Fang, R. X. 2009. A critical domain of the Cucumber mosaic virus $2 \mathrm{~b}$ protein for RNA silencing suppressor activity. FEBS Lett. 583:101-106.

Ye, R., Wang, W., Iki, T., Liu, C., Wu, Y., Ishikawa, M., Zhou, X., and Qi, Y. 2012. Cytoplasmic assembly and selective nuclear import of Arabidopsis Argonaute4/siRNA complexes. Mol. Cell 46:859-870.

Yu, A., Lepère, G., Jay, F., Wang, J., Bapaume, L., Wang, Y., Abraham, A. L., Penterman, J., Fischer, R. L., Voinnet, O., and Navarro, L. 2013. Dynamics and biological relevance of DNA demethylation in Arabidopsis antibacterial defense. Proc. Natl. Acad. Sci. U.S.A. 110:2389-2394.

Zhang, C., Wu, Z., Li, Y., and Wu, J. 2015. Biogenesis, function, and applications of virus-derived small RNAs in plants. Front. Microbiol. 6:1237

Zhang, X., Zhang, X., Singh, J., Li, D., and Qu, F. 2012. Temperaturedependent survival of Turnip crinkle virus-infected Arabidopsis plants relies on an RNA silencing-based defense that requires DCL2, AGO2, and HEN1. J. Virol. 86:6847-6854.

Zhang, X., Zhao, H., Gao, S., Wang, W. C., Katiyar-Agarwal, S., Huang, H. D., Raikhel, N., and Jin, H. 2011. Arabidopsis Argonaute 2 regulates innate immunity via miRNA393(*)-mediated silencing of a Golgilocalized SNARE gene, MEMB12. Mol. Cell 42:356-366.

Zilberman, D., Cao, X., and Jacobsen, S. E. 2003. ARGONAUTE4 control of locus-specific siRNA accumulation and DNA and histone methylation. Science 299:716-719. 